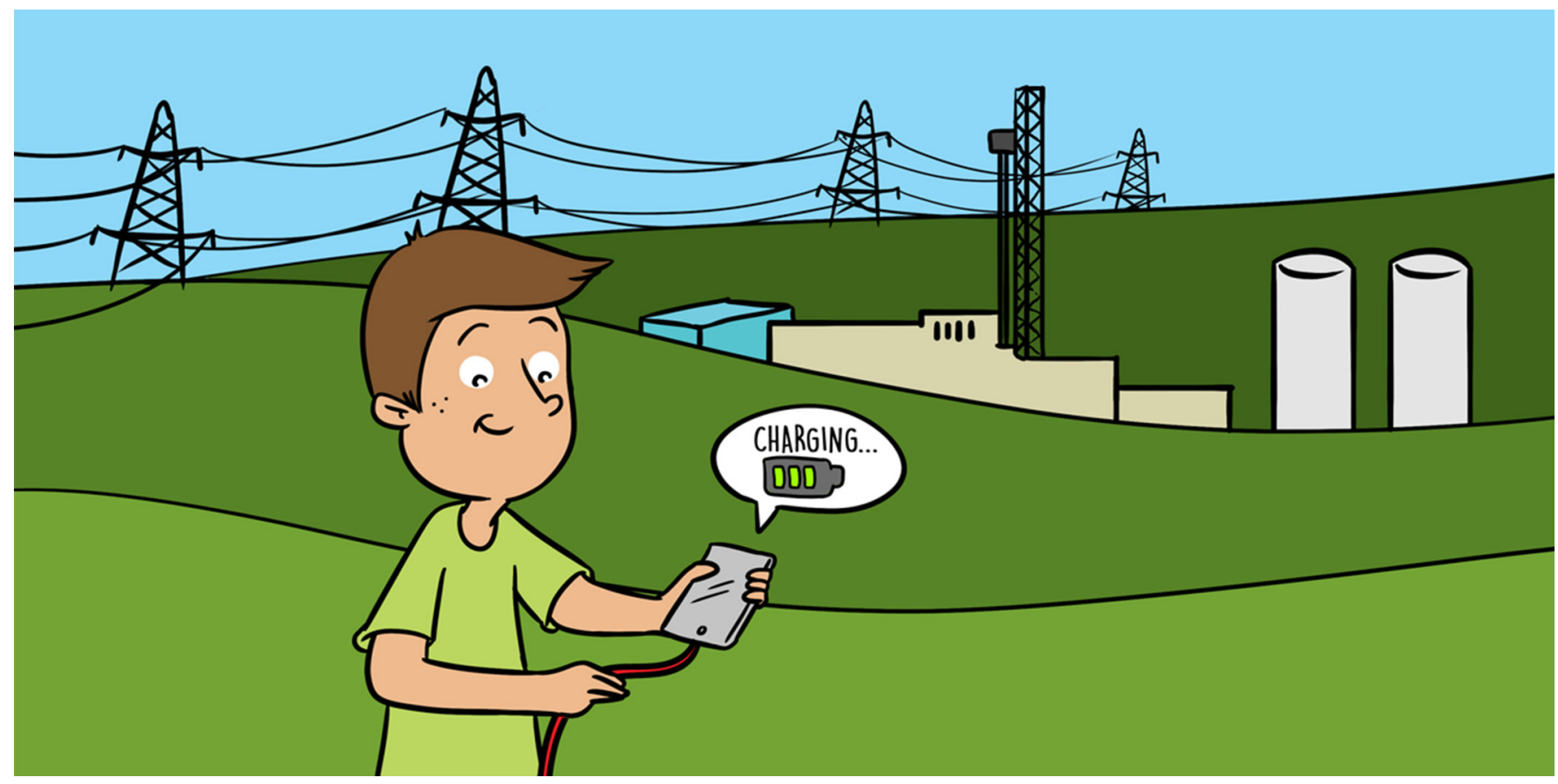

\title{
HARNESSING THE HEAT BENEATH OUR FEET: GEOTHERMAL ENERGY
}

\section{Susan Hamm * and Elisabet Metcalfe}

Geothermal Technologies Office, US Department of Energy, Washington, DC, United States

\section{YOUNG REVIEWERS:}

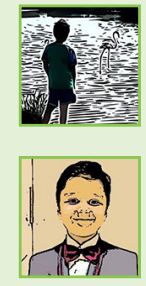

LUKE

AGE: 9

VARDHAN

AGE: 8
Did you know that, deep down, the Earth is really hot and that this heat can generate energy? This energy, called geothermal energy, can create electricity all over the world! It all starts with water. Water is found inside rocks nearly everywhere, even very deep beneath the Earth's surface where it is very hot. The water inside hot rocks is very hot as well, and when this fluid comes to the Earth's surface, it can generate electricity that can turn on a lightbulb, charge your phone, and even power your car! Geothermal energy is green energy! It does not release carbon dioxide into the atmosphere, is nearly inexhaustible, and available 24/7, because the interior of the Earth is always hot. In the future, scientists hope to expand geothermal energy use with technology improvements, bringing this powerful, fascinating energy into even more cities and towns.

\section{WHAT IS GEOTHERMAL ENERGY?}

Geothermal energy is renewable energy that is harnessed from the heat inside the Earth. We can use this energy not only for 


\section{GEOTHERMAL \\ ENERGY}

Thermal (heat) energy generated and stored in the Earth.

\section{RENEWABLE}

ENERGY

Energy collected from resources that are naturally replenished in a human lifetime.

\section{TECTONIC PLATES}

Pieces of the Earth's crust that fit together like a jigsaw puzzle. Over time, the plates move and interact with each other, leading to volcanic and earthquake activity on their edges.

\section{GIGAWATT}

(USUALLY

ABBREVIATED GW)

A measure of energy. 1 GW can power about $1,000,000$ homes. electricity, but also for heating and cooling buildings and for spas and hot springs.

But where does this heat come from? The heat at the center of the Earth is a byproduct of chemical and nuclear reactions happening deep in the Earth's core-reactions that have been occurring for billions of years. A common byproduct of these reactions is heat, which then slowly migrates up through the Earth until we can reach it by drilling into the ground. Because these reactions deep inside the earth will continue to happen, any heat we use will be replaced, or renewed. Geothermal energy, along with solar energy, wind energy, and hydropower, is considered a renewable energy source because we can use it forever.

\section{WHERE DO WE FIND GEOTHERMAL ENERGY?}

Although heat from the center of the Earth is migrating to the surface everywhere, the heat is concentrated at the edges of tectonic plates. Tectonic plates are pieces of the Earth's surface that fit together like a jigsaw puzzle and move around slowly, about as fast as your fingernails grow. These plates can grind up against each other, or slip under each other, so their edges are very hot and are considered dynamic places. In fact, the edges of tectonic plates are marked by lots of earthquakes, like in California, and volcanoes, like in Japan.

For example, the edge of the Pacific Plate is called the Ring of Fire, because of the especially high number of earthquakes and volcanoes that occur there (see Figure 1). The western United States is a part of the Ring of Fire, so more heat is brought to the Earth's surface in states like Nevada and California. That is where you will find all of the current geothermal power plants in the U.S.

Check out the tectonic plate map above and look at the countries through which plate boundaries cross. Do you notice a pattern? Countries with a lot of geothermal energy, like Iceland and Indonesia, also sit right on top of a plate boundary. Think of all the geothermal energy potential across the entire globe!

\section{HOW MUCH GEOTHERMAL ELECTRICITY IS CURRENTLY PRODUCED?}

A lot of gigawatts! A gigawatt, usually abbreviated as GW, can power about $1,000,000$ homes. There is about $12.8 \mathrm{GW}$ of geothermal-based electricity produced worldwide and about $3.5 \mathrm{GW}$ in the U.S. alone. $3.5 \mathrm{GW}$ can power about 3,500,000 homes, which is equivalent to almost all the households in the entire state of Georgia! That might seem like a lot, but it is about to get bigger: there is about $1.3 \mathrm{GW}$ 
Figure 1

A world map showing tectonic plates and plate boundaries. The Ring of Fire runs along the perimeter of the Pacific Plate (National Park Service)

Convergent boundaries, shown in red, are where plates are moving toward each other. Divergent boundaries, shown in white, are where plates are moving away from each other. Transform boundaries, shown in gold, are where plates are sliding past each other. The yellow dots represent earthquake activity, which you can see is heaviest at the edges of the plates. Map of Tectonic Plates by the National Park Service.

\section{PERMEABILITY}

The ability of a material to allow fluids to pass through it, usually through fractures or small interconnected holes in the material.

\section{GEOTHERMAL RESERVOIR}

A place where energy can be extracted from the ground because the conditions are just right.

\section{TURBINE}

A mechanical device that spins and produces electrical power when combined with a generator.

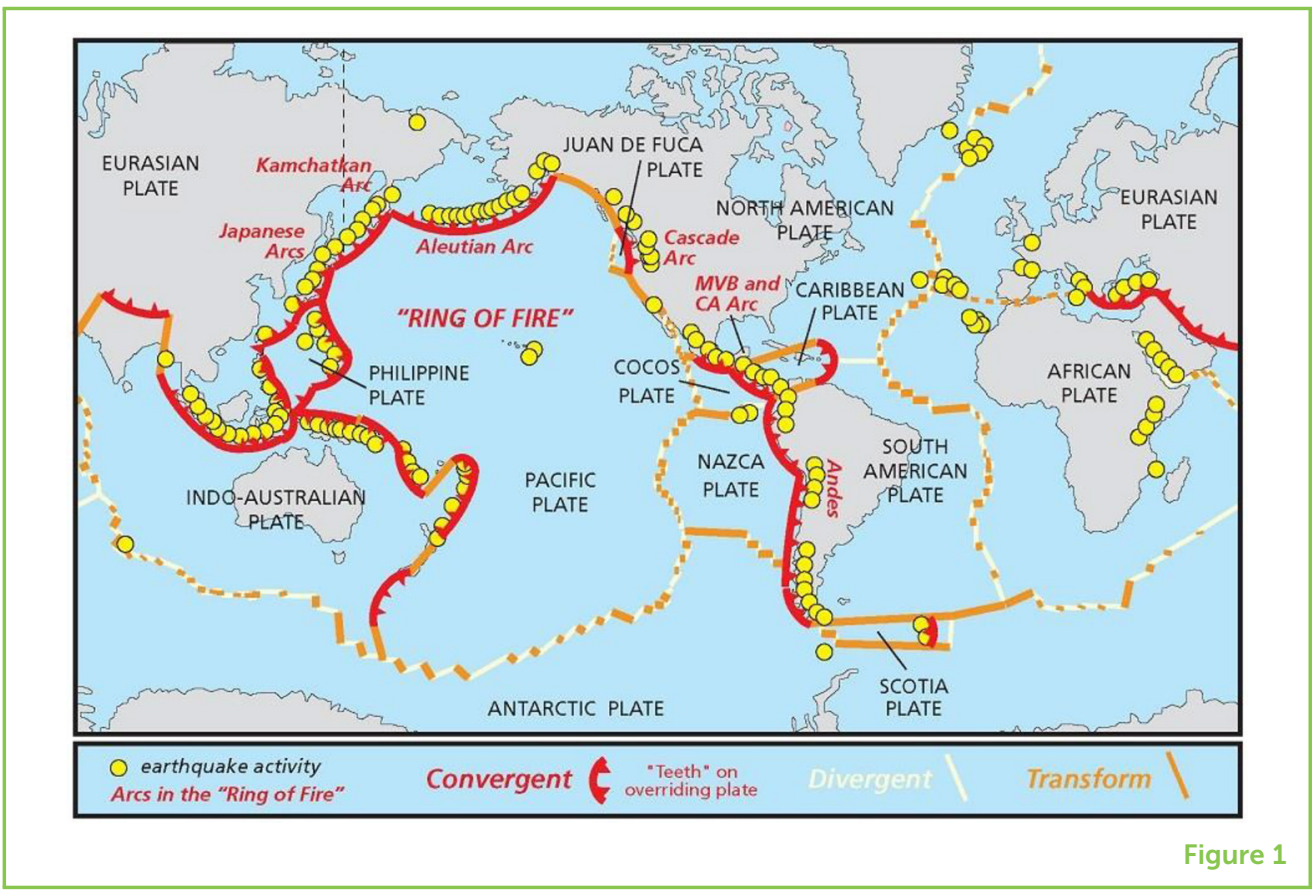

of additional electricity from geothermal energy under development right now!

\section{WHAT MAKES UP A GEOTHERMAL RESERVOIR?}

To be able to harness the geothermal energy deep in the Earth, we need three ingredients: (1) heat, (2) fluid, and (3) permeability, or pathways through the rock.

As we have already discussed, heat from the center of Earth migrates to the Earth's surface naturally, and is found everywhere underground, although the amount of heat varies slightly from place to place.

We also need fluid inside underground rocks to absorb heat and bring it to the surface for us. This fluid is not your average water; it is not like water that comes out of your tap, or ocean water, or agricultural water, or anything that you have ever seen before. This fluid has weird colors, strange smells, and flows differently.

Lastly, we need to have pathways for that water to flow underground. These pathways are usually made up of fractures, or cracks in the rocks, which are very tiny and connected to each other. These fractures allow the fluid to circulate slowly and increase in temperature.

When these three things occur together, they create a geothermal reservoir. We can pump the hot water out of the reservoir, send it through a power plant, use it to spin a turbine and generate electricity. Then, that electricity can be sent out to power homes via transmission 
Figure 2

This figure shows the circulation of fluids at a power plant harnessing energy from a

geothermal reservoir

(Department of

Energy). Hot water

from far below the surface is pumped up to the production well and is sent to the power plant. Inside the plant, the heat from the water is used to spin a turbine, creating electricity. Once the heat is used, the water is now cold, and is pumped back into the subsurface through the injection well. That water will now heat up again over time and go through the cycle again.

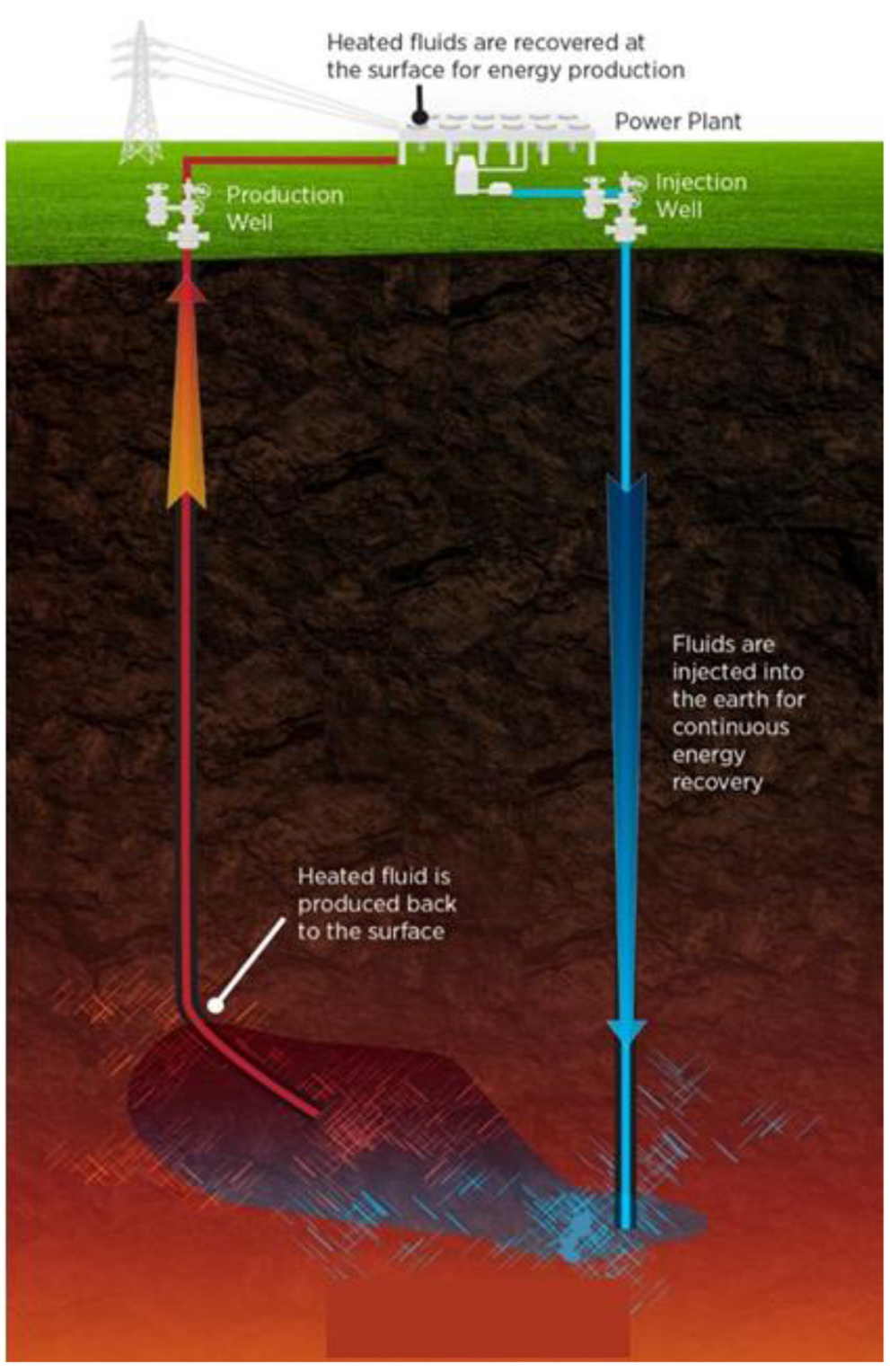

Figure 2

lines. If we do not have these three things together, then there is no way to generate any power from the geothermal energy.

You may be asking, "well, the heat may be renewable, but what about the fluid? Can you use up all the hot fluid?" Actually, after the hot water has been used for energy production, it can be put back underground, where the water can be reheated and can generate electricity again (see Figure 2). It is a perfect circle!

\section{CAN HUMANS CREATE THEIR OWN GEOTHERMAL RESOURCES?}

There is a lot of research going on right now to figure out how to create geothermal reservoirs in places where there is hot rock underground. 
In some locations, there are hot rocks, but little permeability or fluids to bring that heat to the surface for energy production. In these instances, it may be possible to inject fluid into the hot rocks and create permeability. This sort of man-made geothermal reservoir would allow geothermal electricity to be produced anywhere. We would not only be able to build geothermal power plants on the Earth's surface, but we could also build geothermal reservoirs underground. This would be revolutionary and could generate almost 500 GW more electricity than is currently produced by geothermal energy.

\section{WHAT KIND OF RESEARCH IS GOING ON TO INCREASE OUR GEOTHERMAL RESOURCES?}

Many people in a lot of different specialties are working toward figuring out how to harness more geothermal energy. For example, computer scientists are teaching computers how to look for hot rocks; engineers are inventing new ways to drill and build geothermal reservoirs; and lots of scientists are getting their hands dirty by getting out of their labs to test their geothermal-related inventions in real-world conditions. Last, but not least, sharing is a huge part of advancing geothermal energy. Sharing data, sharing ideas, talking about the future, and contributing to other scientists' research. The geothermal community is a tight-knit family, and they are always cheering each other on and helping each other out.

In summary, we have introduced what geothermal energy is and where it can be found, as well as what it takes to have or create a geothermal reservoir. Geothermal energy is good for the environment, nearly

INEXHAUSTIBLE

Never-ending; cannot run out. inexhaustible, always available, and in the future, can help power and heat cities and towns throughout the world.

SUBMITTED: 15 February 2019; ACCEPTED: 19 July 2019;

PUBLISHED ONLINE: 07 August 2019.

EDITED BY: Antonio Olita, Institute of Atmospheric and Climate Sciences, National Research Council, Italy

CITATION: Hamm S and Metcalfe E (2019) Harnessing the Heat Beneath Our Feet: Geothermal Energy. Front. Young Minds 7:105. doi: 10.3389/frym.2019.00105

CONFLICT OF INTEREST STATEMENT: The authors declare that the research was conducted in the absence of any commercial or financial relationships that could be construed as a potential conflict of interest.

COPYRIGHT @ 2019 Hamm and Metcalfe. This is an open-access article distributed under the terms of the Creative Commons Attribution License (CC BY). The use, distribution or reproduction in other forums is permitted, provided the original author(s) and the copyright owner(s) are credited and that the original publication in this journal is cited, in accordance with accepted academic practice. No use, 

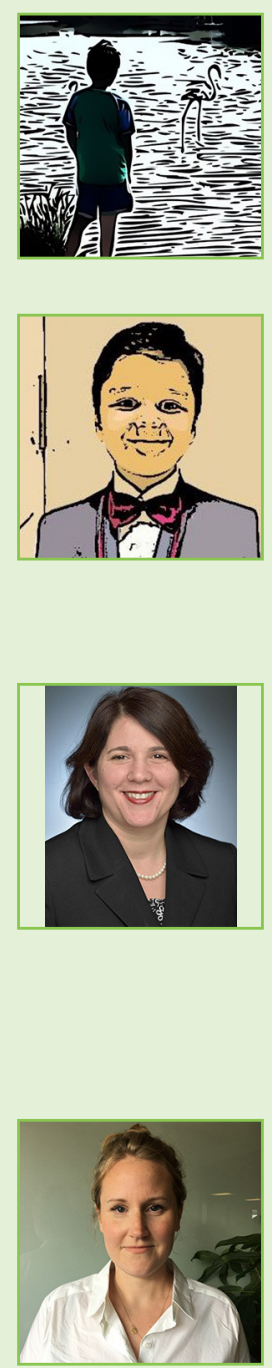

distribution or reproduction is permitted which does not comply with these terms.

\section{YOUNG REVIEWERS}

\section{LUKE, AGE: 9}

I am in the fourth grade, I love to play soccer and basketball. I also like music a lot. When I grow up, I want to be a computer scientist! I like learning about science and I really like math.

\section{VARDHAN, AGE: 8}

My name is Vardhan and I am 8 years old. I enjoy cricket and reading books on outer space. My favorite subjects are Math and English.

\section{AUTHORS}

\section{SUSAN HAMM}

Dr. Susan G. Hamm is the Director for Geothermal Technologies at the U.S. Department of Energy. She leads efforts to lower costs and risks so more geothermal energy can be used for electricity and heat. Dr. Hamm has also worked at the National Science Foundation and the Department of Homeland Security, and she has been a legislative assistant in the U.S. Congress. She holds a B.A. in Geology from Amherst College as well as a M.S. in Geophysics and a Ph.D. in Material Sciences from the University of Minnesota. *susan.hammaee.doe.gov

\section{ELISABET METCALFE}

Elisabet Metcalfe is a Scientist in the Geothermal Technologies Office at the U.S. Department of Energy, Office of Energy Efficiency and Renewable Energy. In this role, Elisabet is involved in project oversight and execution of cutting-edge EGS RD\&D, leads the annual student competition, and develops the communications strategy for geothermal initiatives. Prior to joining DOE, Elisabet worked within FEMA's National Flood Insurance Program in Washington, DC. Elisabet holds an M.S. in Earth Science from the University of Maine-Orono and a B.S. in Geology and Geophysics from University of Wisconsin-Madison. 